\title{
Interdependence And Volatility Spillovers Under Market Reforms: The Case Of National Stock Exchange
}

B.J.Queensly Jeyanthi, Jayaraj Annapackiam College for Women (Autonomous), India

\begin{abstract}
India, one of the emerging markets in Asia initiated the financial sector reforms by introducing international practices in its financial market. In this paper an attempt has been made to examine whether and to what extent, Indian stock market is integrated with stock markets in the United States, Japan and U.K before and after the structural changes. It also examines whether such a relationship, if it exists, is affected by the structural changes that began in 1998 using daily data for the period April 1998 to December 2008. The main findings are: No evidence of long run relationships was found between the stock prices of India and its major trading partners before and after the structural changes. Second, in terms of short - run movements of international stock market returns, bidirectional Granger causality exist between the stock returns of India and those of US and UK and Japan after the structural changes but unidirectional relationship exists between India and the UK before the structural changes period. The estimates from causality type models suggest that volatility spillovers from UK and Japan were non-existent prior to structural changes and volatility spillovers from US and Japan have become quite pronounced after the structural changes. The results identify the US and Japan markets as the main sources of volatility spillovers for the NSE.
\end{abstract}

Keywords: Volatility Spillovers, Granger Causality, ARCH, Structural changes

\section{INTRODUCTION}

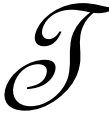

he growing issues of financial market integration have recently attracted the attention of investors and academics. The spillover or contagion effect across financial assets has been the focus of much interest from academics and financial market regulators in recent years. After the stock market crash in 1987, there was a considerable interest in empirical and theoretical investigations of the linkages between capital markets. The economic and financial turmoil that struck Asia in mid 1997 has triggered this interest. It is well known that the linkages among stock markets vary over time and the nature of any time variation is of potentially great interest. Generally, changes in the stock indices are influenced by the flow of market information. Studying the stock market movements is the joint study of the spillover of price changes and the volatility of price changes. Transmission mechanisms between the returns and volatilities of different stocks are important for a number of reasons. The transmission mechanisms tell us something about market efficiency. Before investing in an asset, investors incorporate information about price movements and volatility in the same asset and related assets listed in different countries. This issue is an important concern for portfolio investors because greater integration among world markets implies stronger co-movements between markets, therefore nullify much of the gain out of diversification across borders, besides being vulnerable to the caprices of global capital. To investment professionals, the study on the volatility spillover and correlation between returns in different markets can provide information useful for asset allocation and risk management purposes. If volatility spillovers are significant between markets, a shock emanating from one market may have a destabilizing impact on other markets. This could amplify the extent and magnitude of the original shock and may threaten the financial system. Financial market volatility affects real economic activity and the proper functioning of financial markets. It is therefore an important subject for policy makers who are responsible for market stability. Thus understanding of inter-market volatility is important for the 
pricing of securities within and across the markets, for international diversification strategies, for hedging strategies and for regulatory policy.

India, one of the major emerging markets in Asia initiated the financial sector reforms by way of adopting international practices in its financial markets. Dematerialization of securities, introduction of electronic trading, central counterparty, rolling settlement, clearing and settlement mechanism, reforms in the carry forward and margin trading system, derivatives trading and increasing activities of multinational corporations have enlarged the growth of Indian capital market.

The main purpose of this paper is to empirically examine whether and to what extent, Indian stock market is integrated with stock markets in the United States, Japan and UK before and after the structural changes. It also addresses the issue of whether such a relationship, if it exists, is affected by the structural changes that began in 1998. Specifically this paper addresses the impact of structural changes on the integration of the NSE in the global market and on the vulnerability of the Indian market to spillover effects originating in major foreign markets

\section{REVIEW OF LITERATURE}

Dynamic linkages among developed and developing world's stock markets have been studied since the late 1960s (Grubel 1968). With the increasing integration of major financial markets around the world, the transmission of stock return movement among major stock has become a much researched topic. Some studies have examined only the return spillover across the markets. While other researchers have examined the impact of some special events such as market crisis, market liberalization etc. on the spillover of information across the national borders, but there are also some studies that focused on the possible factors or in short, the determinants of such information spillover among different markets.

Manning (2002), Sharma and Wongbangpo (2002), Johnson and Soenen (2002) Besler and Yang (2003) Hisiao (2003), Nalini Prava Tripathy (2005), Narayan Smith (2005), Deepak Chawla (2005), Valadkhani and Chancharat 92007), Hong Rim and Robert Setaputra (2008), etc have analysed return spillover across the market. Apart from examining only the degree of spillover among the markets, studies like Cifarelli (2000), Hashmi (2001), Tan (2001), Ratanapakorn (2002), Jang (2002), Yang (2002), Yang et al (2003), Kim (2005), Click and Plummer (2005), Kuper and Lestano (2006), Foo, siew-Yen et al (2008) Lucey and Voronkova (2008) etc. have also examined the effect of market crisis on the information spillover across the border of a country. Almost all of the above studies have examined the effect of 1997 / 98 Financial Crisis. Unlike only return spillover, some studies examined the spillover of information both in terms of return and volatility includes Laurence Fung and Ip-wing Yu (2001) Barro (2001), Kumar (2002), Hahm (2003),Tatsuyoshi Miyukoshi (2003), Darret and Benkato (2003), Harris and Pisedtasalasai (2005), Kim (2005), Abraham and Seyyed (2006), Baur and Jung (2006), Egert and Kocenda (2007), Chuang (2007), Gêbka and Serwa (2007), Morana and Beltratti (2008), Diebold and Yilmaz (2008), Harju and Hussain (2008), Yu and Hassan (2008), Alkulaib (2008) etc. Following the ARCH family of statistical models, Hamao (1990), Christofi (1999), Kim (2005), Wang (2005), Baur and Jung (2006) etc. have examined the volatility spillover among the developed and emerging European, American, and Asian equity markets with the US. Most of the studies have shown a unidirectional volatility spillover from the US to other countries.

Though there is a large number of a literature on the spillover of information across the markets, only a few of them have focused on the Indian equity market. Kumar (2002), Nath (2003), Mukherjee (2005), Wang (2005), Khan Masood Ahmad, et al (2005), Deepak Chawla ( 2005), Queensly Jeyanthi B.J. and Pandian ( 2008), Bhar R., and Biljana Nikolova (2009) etc. are some of the studies where Indian equity market has been treated as one of the market the price and volatility of which affects and also is affected by the price and volatility of other markets.

\section{DATA}

Date employed in this study are daily closing stock market indices for the United States (Nasdaq), UK (FTSE) Japan (Nikkei) and India (Nifty).The time period of the data is from 1- 4 - 1998 to 31-12-2008. The daily data have more than 2600 observations for each market. Closing values are used to represent the market. However, when the cointegration tests are conducted, some daily observations are deleted because of different holiday. The 
pair wise cointegration test is conducted between the stock market index of India and those of the major developed markets. To know the impact of the structural changes on the level of integration, the full sample period is sub divided into two periods. The first sub-sample is from 1 April 1988 to 31 March 2004, while the second sub-sample is from 1 April 2004 to 31 December 2008. For each country, daily returns, $r_{t}$, are computed as the first differences of the natural logarithm of $\mathrm{P}_{\mathrm{t}}$, which is the daily close values of the indexes multiplied by 100. i.e., $\quad r_{t},=\left(\operatorname{In} P_{t}-I n\right.$ $\left.\mathrm{P}_{\mathrm{t}-1}\right) * 100$

\section{METHODOLOGY}

The augmented Dickey-Fuller (ADF) unit-root test was employed to examine the stationary property of market prices. The null hypothesis of nonstationarity (unit root) and alternative hypothesis (no unit root) of stationarity are tested for each data series. Since the methodology of testing for unit roots is well known, the details are omitted.

\section{COINTEGRATION}

Cointegration analysis is used to investigate long term relationship between Indian and developed stock markets and it is estimated by ordinary least squares under the following formula:

$\mathrm{X}_{\mathrm{t}}=\beta_{1}+\delta \mathrm{Y}_{\mathrm{t}}+\mu_{\mathrm{t}}$

The Engle Granger Augmented Dickey-Fuller test is applied on the 'cointegrtating residuals' $\mu_{t}$ obtained from the equation (1). The formula for EG-ADF test is as follows:

$\Delta \mu_{t}=-\delta \mu_{t-1}+a_{i} \sum_{i=1}^{m} \Delta \mu_{t-1}+\mu_{t}$

$\Delta \mu_{t}$ represents the first differences of the residuals

\section{GRANGER CAUSALITY}

The dynamic linkage is examined using Granger's (1969) causality test. Formally, a time series $\mathrm{x}_{\mathrm{t}}$ Granger - causes another time series $y_{t}$ if series $y_{t}$ can be predicted with better accuracy by using past values of $x_{t}$ rather than by not doing so, other information being identical. In other words, variable $\mathrm{x}_{\mathrm{t}}$ fails Granger -cause $\mathrm{y}_{\mathrm{t}}$ if

$\operatorname{Pr}\left(\mathrm{y}_{\mathrm{t}+\mathrm{m}} \mid \Omega_{\mathrm{t}}\right)=\operatorname{Pr}\left(\mathrm{y}_{\mathrm{t}+\mathrm{m}} \mid \Psi_{\mathrm{t}}\right)$,

Where $\operatorname{Pr}\left(\mathrm{y}_{\mathrm{t}+\mathrm{m}} \mid \Omega_{\mathrm{t}}\right)$ denotes conditional probability of $\mathrm{y}_{\mathrm{t}}, \Omega_{\mathrm{t}}$ is the set of all information available at time $\mathrm{t}$, and $\operatorname{Pr}\left(\mathrm{y}_{\mathrm{t}+\mathrm{m}} \mid \Psi_{\mathrm{t}}\right)$ denotes conditional probability of $\mathrm{y}_{\mathrm{t}}$ obtained by excluding all information on $\mathrm{x}_{\mathrm{t}}$ from $\mathrm{y}_{\mathrm{t}}$ this set of information is depicted as $\Psi_{\mathrm{t}}$.

The hypotheses are tested in the context of VAR of the following form:

$$
\begin{aligned}
& x_{t}=\alpha_{0}+\sum_{j=1}^{k} \gamma_{j} \mathrm{x}_{t-j}+\sum_{j=1}^{k} \beta_{j} \mathrm{y}_{t-j}+\mu_{x t} \\
& y_{t}=\alpha_{0}+\sum_{j=1}^{k} \gamma_{j} \mathrm{x}_{t-j}+\sum_{j=1}^{k} \beta_{j} \mathrm{y}_{t-j}+\mu_{y t}
\end{aligned}
$$


Where $\mathrm{k}$ is a suitably chosen positive integer, $\gamma_{j}$ and $\beta_{j}, \mathrm{j}=0,1 \ldots \ldots \mathrm{k}$ are parameters and $\alpha$ ' are constants and $\mu_{t}$ 's are disturbance terms with zero means and finite variances. The null hypothesis that $y_{t}$ does not Granger - cause $x_{t}$ is not accepted if the $\beta_{j}$ 's, $\mathrm{j}>0$ in equation (4) are jointly significantly different from zero using a standard joint test (e.g., and F test). Similarly, $x_{t}$ Granger - causes $y_{t}$, if the $\lambda_{j}$ 's $\mathrm{j}>0$ coefficients in equation (5) are jointly different from zero.

\section{Testing for ARCH}

The null hypothesis of there is no autocorrelation in the error variance (no $\mathrm{ARCH}$ ) is given by an $\mathrm{ARCH}(\mathrm{p})$ process

$H_{O}: \beta_{1}=\beta_{2}=\ldots . .=\beta_{p}=0$

$H_{1}: \beta_{1} \neq \beta_{2} \neq \ldots \ldots \neq \beta_{p}=0$

The above hypothesis was tested by the approach proposed in Engle (1982). Residual series are generated by regressing $x_{t}$ and $y_{t}$ on constant such as:

$$
\begin{aligned}
& x_{t}=\alpha+\mu_{x t} \\
& y_{t}=\alpha+\mu_{y t}
\end{aligned}
$$

And then estimate residuals

$$
x_{t}-\hat{\alpha}=\hat{\mu}_{x t} ; y_{t}-\hat{\alpha}=\hat{\mu}_{y t}
$$
same series.

The squared residuals are then regressed on a constant and p lagged values of the squared residuals of the

$$
\hat{\mu}_{x t}^{2}=\beta_{0}+\left(\sum_{m=1}^{p} \beta_{m} \hat{\mu}^{2}{ }_{x t-m}\right)+\varepsilon_{t}
$$

Similarly, ARCH model can be applied for other series.

The null hypothesis of $\mathrm{H}_{0}$ by computing $\mathrm{nR}^{2}$, where $\mathrm{R}^{2}$ is the coefficient of the test regression. In large samples $n R^{2}$ follows the chi-square distribution with df equal to the number of autoregressive terms in the auxiliary regression. In order to test the spillover effect of volatility of one series to another series, Granger Causality test is applied:

$$
\begin{aligned}
& \hat{\mu}_{x t}^{2}=\delta_{0}+\sum_{j=1}^{k} \lambda_{j} \hat{\mu}_{x t-j}^{2}+\sum_{j=1}^{k} \eta_{j} \hat{\mu}_{y t-j}^{2}+e_{x t} \\
& \hat{\mu}_{y t}^{2}=\delta_{0}+\sum_{j=1}^{k} \lambda_{j} \hat{\mu}_{x t-j}^{2}+\sum_{j=1}^{k} \eta_{j} \hat{\mu}_{y t-j}^{2}+e_{y t}
\end{aligned}
$$


$\lambda_{j}$ and $\eta_{j}, \mathrm{j}=0,1, \ldots \ldots \mathrm{k}$ are parameters and $\delta$ 's are constants; and e's are disturbance terms with zero means and finite variances. The null hypothesis that $\hat{\mu}_{y t}^{2}$ does not Granger - cause $\hat{\mu}_{x t}^{2}$ is not accepted if the $\eta_{j}$ 's j>0 in equation (11) and the null hypothesis that $\hat{\mu}_{x t}^{2}$ does not Granger cause $\hat{\mu}_{y t}^{2}$ is not accepted if the $\lambda_{j}$ 's, j $>0$ in equation (12) are jointly significantly different from zero using a standard joint test (e.g., an F test)

\section{EMPIRICAL RESULTS}

Table 1 presents the descriptive statistics for the daily stock return of NSE and the three matured markets. It is very clear from the Table 1 that NSE exhibits the highest average daily return across all markets $(=0.03164 \%$ per day) but Nasdaq exhibits highest variability among the four markets as measured by the standard - deviation of returns ( $=2.520 \%$ per day). The data further suggest that the NSE appears to have behaved differently in the periods before and after the structural changes. Table 2 delineates that the mean daily return and volatility before and after the structural changes ranges from $0.030 \%$ to $0.043 \%$ and from $1.63 \%$ to $1.87 \%$ respectively.

Table 1: Descriptive Statistics of Daily Stock Returns (April 1998 - December2008)

\begin{tabular}{|l|c|c|c|c|}
\hline \multicolumn{1}{|c|}{ Country } & Mean & Std.Dev & Skewness & kurtosis \\
\hline INDIA & 0.03164 & 1.748 & -0.525 & 4.561 \\
\hline US & -0.000544 & 2.252 & 0.168 & 3.956 \\
\hline UK & -0.0107 & 1.319 & -0.094 & 5.942 \\
\hline JAPAN & -0.0230 & 1.607 & -0.272 & 6.409 \\
\hline
\end{tabular}

Table 2: Descriptive Statistics of Daily Stock Returns (April 1998 - March 2004)

\begin{tabular}{|c|c|c|c|c|}
\hline Country & Mean & Std.Dev & Skewness & Kurtosis \\
\hline INDIA & 0.03060 & 1.639 & -0.151 & 2.296 \\
\hline US & 0.0103 & 2.686 & 0.186 & 2.074 \\
\hline UK & -0.0233 & 1.550 & 0.002 & 1.352 \\
\hline JAPAN & -0.0200 & 1.3342 & -0.066 & 1.472 \\
\hline \multicolumn{5}{|c|}{ Post structural changes period (April 2004 - December 2008) } \\
\hline Country & Mean & Std.Dev & Skewness & Kurtosis \\
\hline INDIA & 0.04317 & 1.8775 & -0.838 & 6.027 \\
\hline US & 0.0143 & 1.5365 & -0.11 & 9.769 \\
\hline UK & 0.0239 & 1.6722 & -0.549 & 11.133 \\
\hline JAPAN & -0.000916 & 1.3011 & -0.131 & 12.208 \\
\hline
\end{tabular}

Table 3 presents the results of ADF test for all the series in their log level. As can be seen in table 3, the ADF test fails to reject the null hypothesis of the existence of a unit root in log levels and hence all the market indices are nonstationary. In contrast, unit root tests reject the same null hypothesis in the log first-differenced form of the series, which indicate that in first-differenced form, all the series are stationary. Therefore, each stock market index is integrated in order one, or I(1). ADF test is well known so it is not given here.

Table 3: Unit Root Test Statistics

\begin{tabular}{|l|c|c|c|c|c|c|}
\hline \multicolumn{9}{|c|}{ Levels } & \multicolumn{3}{c|}{ First Difference } \\
\hline \multicolumn{1}{|c|}{ Country } & $\mathbf{1 9 9 8 - 2 0 0 8}$ & $\mathbf{1 9 9 8 - 2 0 0 4}$ & $\mathbf{2 0 0 4 - 2 0 0 8}$ & $\mathbf{1 9 9 8 - 2 0 0 8}$ & $\mathbf{1 9 9 8 - 2 0 0 4}$ & $\mathbf{2 0 0 4 - 2 0 0 8}$ \\
\hline INDIA & -1.803 & -1.367 & -0.314 & $-37.60^{* *}$ & $-36.047 * *$ & $-25.125^{* *}$ \\
\hline US & -1.884 & -1.872 & -0.412 & $-41.14^{* *}$ & $-30.225^{* *}$ & $-29.194 * *$ \\
\hline UK & -1.903 & -2.400 & -0.182 & $-4.30^{* *}$ & $-28.994 * *$ & $-28.233^{* *}$ \\
\hline JAPAN & -1.462 & -1.688 & -0.778 & $-38.58^{* *}$ & $-28.585^{* *}$ & $-25.972^{* *}$ \\
\hline
\end{tabular}

The critical values for ADF test are -.3.96 and -3.41 at 1 per cent and 5 per cent respectively.

* Significant at $1 \%$ level. 
Cointegration analysis is used to investigate long term relationship between NSE and the matured markets. The analysis recognizes the non - stationarity of the time series. Economically speaking, two variables will be cointegrated if they have long-term, or equilibrium relationship between them (Engle and Granger 1987). Because all the stock price indices are non - stationary, the Engle Granger cointegration test is conducted. The results shown in Table 4 depicts that there is no long term relationship between the stock markets for the full sample period, 1998 2008 and the pre and post period. The null hypothesis of no cointegration cannot be rejected for all pair-wise cases.

Table 4: The Engle- Granger ADF Cointegration Test Results

\begin{tabular}{|l|c|c|c|}
\hline \multicolumn{1}{|c|}{ Country } & $\mathbf{1 9 9 8 - ~ 2 0 0 8}$ & $\mathbf{1 9 9 8 - 2 0 0 4}$ & $\mathbf{2 0 0 4 - 2 0 0 8}$ \\
\hline INDIA - US & -0.316 & -0.935 & -0.615 \\
\hline INDIA - UK & 0.391 & -0.840 & -0.521 \\
\hline INDIA - JAPAN & -0.010 & -0.915 & -0.615 \\
\hline
\end{tabular}

The critical value for EG -ADF tests at 5\% level of significance is -3.17 .

Granger causality test is used to examine the pair - wise short - run interactions between different stock markets. According to the results presented in the Table 5 in the short term there is a unidirectional Granger causality running from UK to India for the full sample period and the pre structural changes period but not in the post structural changes period. Bidirectional Granger causality exists between India and US and Japan in the whole sample period and in the pre structural but in the post structural changes period bidirectional relationship exists between India and UK also. The degree of Granger causality was very high in the post structural changes period.

Table 5: Granger Causality Test Results

\begin{tabular}{|c|c|c|}
\hline \multicolumn{3}{|c|}{ Full Sample Period April 1998 - December 2008} \\
\hline & F-Statistic & Causality Inference \\
\hline India $\rightarrow$ US & $2.75^{*}$ & Reject \\
\hline $\mathrm{US} \rightarrow$ India & $18.91 *$ & Reject \\
\hline India $\rightarrow$ Uk & 1.37 & Accept \\
\hline $\mathrm{UK} \rightarrow$ India & $29.82 *$ & Reject \\
\hline India $\rightarrow$ Japan & $10.27 *$ & Reject \\
\hline Japan $\rightarrow$ India & $10.11^{*}$ & Reject \\
\hline \multicolumn{3}{|c|}{ Pre structural changes period April 1998 - March 2004} \\
\hline India $\rightarrow$ US & $5.60 *$ & Reject \\
\hline US $\rightarrow$ India & $12.52 *$ & Reject \\
\hline India $\rightarrow$ Uk & 0.19 & Accept \\
\hline $\mathrm{UK} \rightarrow$ India & $2.80 *$ & Reject \\
\hline India $\rightarrow$ Japan & $7.53 *$ & Reject \\
\hline Japan $\rightarrow$ India & $3.18^{*}$ & Reject \\
\hline \multicolumn{3}{|c|}{ Post structural changes period April 2004 - December 2008} \\
\hline India $\rightarrow$ US & $8.40 *$ & Reject \\
\hline US $\rightarrow$ India & $110.18 *$ & Reject \\
\hline India $\rightarrow$ UK & $3.15 *$ & Reject \\
\hline $\mathrm{UK} \rightarrow$ India & $34.42 *$ & Reject \\
\hline India $\rightarrow$ Japan & $7.52 *$ & Reject \\
\hline Japan $\rightarrow$ India & $11.62 *$ & Reject \\
\hline
\end{tabular}

* Significant at $1 \%$ level.

\section{Assessing Market Volatility}

Analyzing the possible impact of structural changes on the market volatility is profoundly important for policy makers and regulators in their deliberations on the costs and benefits of liberalization programs. Therefore, besides examining stock return interdependencies between the NSE and other matured markets, the volatility of the NSE before and after the structural changes and volatility interdependencies across markets are explored. ARCH 
process is used to measure volatility in stock returns of the four markets and, in the case of India, also in the two sub - periods before and after structural changes. Table 6 reports the ARCH based estimates of time varying conditional standard deviation of these markets over the full sample period and the two sub sample period. Among all the markets, US is quite volatile compared to other markets. Panel B in Table 6 assembles the ARCH - based measures of time - varying standard deviations over the two sub- periods. Similar to the implications from time - invariant standard deviations, results from the ARCH models also suggest that the volatility of NSE has increased after the structural changes.

Table 6: Stock return volatility Using ARCH process

\begin{tabular}{|l|c|}
\hline \multicolumn{2}{|c|}{ Countries } \\
\hline \multicolumn{2}{|c|}{ Panel A: Full Period (April 1998 - Dec 2008) } \\
\hline INDIA & April 1998 - Dec 2008 \\
\hline US & 1.74 \\
\hline UK & 2.24 \\
\hline JAPAN & 1.29 \\
\hline \multicolumn{2}{|c|}{ Panel B: Sub period estimates for India } \\
\hline Pre structural changes Period & 1.59 \\
\hline Post structural changes Period & 1.63 \\
\hline
\end{tabular}

To test the volatility clustering ARCH model on each series is applied. Estimation of volatility is of crucial importance because higher volatility makes financial investment more risky. The results are given in Table 7. The results reveal that there is significant ARCH effect (volatility clustering) in each series.

Table 7: ARCH test for Volatility

\begin{tabular}{|l|c|c|}
\hline \multicolumn{1}{|c|}{ Variables } & Obs*R-squared & Arch effect \\
\hline INDIA & 352 & Present \\
\hline US & 244 & Present \\
\hline UK & 568 & Present \\
\hline JAPAN & 141 & Present \\
\hline
\end{tabular}

Final task in this paper is to examine which of the matured markets constitutes the main causal force behind volatility in the NSE. To examine the spillover effect of volatility from the matured markets to India again Granger causality test is applied to the residual series. Table 8 reports the volatility spillovers from the matured markets to volatility in the NSE.

Table 8: Time - varying Conditional Volatility spillovers from Matured markets to the NSE

\begin{tabular}{|l|c|c|c|}
\hline \multicolumn{1}{|c|}{ Period } & US & UK & JAPAN \\
\hline Pre structural changes & $4.20^{*}$ & 0.96 & 1.52 \\
\hline Post structural changes & $116.53^{* *}$ & 0.48 & $103.63^{* *}$ \\
\hline
\end{tabular}

* Significant at $1 \%$ level

These results clearly suggest that volatility spillovers from US and Japan market to NSE were very high after the structural changes. But there was no volatility spillover from UK. In the first period the NSE appeared quite segmented from the UK and Japan as volatility spillovers from these two matures markets were statistically non-existent.

\section{CONCLUSION}

This study examines the long - run and short - run relationships and volatility relationships between the 
stock prices of India and its major trading partners (US, UK and Japan), using daily data for the period April 1998 to December 2008. Based on the cointegration results, no evidence of long - run relationships was found between the stock price indices of India and its major trading partners before and after the structural changes. The policy implication of this finding for international investors is quite straightforward: in the long run, there are potential gains which can be leveraged by astute investors through portfolio diversification across different international markets.

Second, in terms of short - run movements of international stock market returns, bidirectional Granger causality exist between the stock returns of India and those of US and UK and Japan after the structural changes but unidirectional relationship exists between India and the UK before the structural changes period. The empirical results presented in this paper support the view that international investors have long - run opportunities for portfolio diversification by acquiring stocks from these countries. However, in the short run, the scope of these opportunities is rather due to systematic and transitory fluctuations which are inherent to stock markets as evidenced by the causality test results.

The estimates from causality - type models suggest that volatility spillovers from UK and Japan were non existent prior to structural changes since then, and volatility spillovers from US and Japan have become quite pronounced after the structural changes. The results identify the US and Japan markets as the main sources of volatility spillovers for the NSE.

\section{REFERENCES}

1. Abraham, A. and Seyyed, F.J. (2006), "Information Transmission between the Gulf Equity Markets of Saudi Arabia and Bahrain", Research in International Business and Finance, 20 (3), 276-285.

2. Barro, J. Robert (2001), "Economic Growth in East Asia before and after the Financial Crisis", NBER Working Paper No, 8330.

3. Baur, D. and Jung R.C. (2006), "Return and Volatility Linkages between the US and the German Stock Market", Journal of International Money and Finance, 25 (4), 598-613.

Bessler, D. A., and Yang, J. (2003), “The Structure of Interdependence in International Stock Markets", Journal of International Money and Finance, 22 (2), 261-287.

4. Bhar-R., and Biljana Nikolova (2009) "Return, volatility spillovers and dynamic correlation in the BRIC equity markets: An analysis using a bivariate EGARCH framework" Global Finance Journal, Volume 9, Issue 3, pp $203-218$.

5. Christofi, A. and Pericli, A. (1999), "Correlation in Price Changes and Volatility of Major Latin American Stock Markets”, Journal of Multinational Financial Management, 9, 79-93.

6. Chuang, Y., Lu., J., \& Tswei, K. (2007) Interdependence of international equity variances: Evidence from East Asian markets, Emerging Markets Review, 8, 311-327

7. Cifarelli, G. and Paladino, G. (2000), "Stock Market Exuberance: Linkages between US and the European Markets”, Working Paper, Quaderni Research del'Osservatorio and Center for Monetary Studies No 121, LUISS Editions

8. Click, R. W. and Plummer, M.G. (2005), "Stock Market Integration in ASEAN After the Asian Financial Crisis", Journal of Asian Economics, 16 (1), 5-28.

9. Darrat, A. F., \& Benkato, O.M. (2003), "Interdependence and volatility spillovers under market liberalization: the case of Istanbul stock exchange", Journal of Business Finance and Accounting 30, 7 , 1089-1114.

10. Deepak Chawla (2005), "Random Walk Hypothesis and Integration among the Indian Stock Market Vis - a - Vis Some Developed Markets", PRAJNAN, 34, 2, pp. 113-127.

11. Diebold Yilmaz (2008) "Measuring financial asset return and volatility spillovers, with application to global equity markets" Working Paper 13811 http://www.nber.org/papers/w13811

12. Foo, Siew-Yen, Wing Keung Wong, and Terence Tai- Leung Chong, (2008), "Are the Asian Equity Markets more Interdependent after the Financial Crisis?”, Economics Bulletin, Vol.6, No.16, pp.1-7.

13. Gêbka, B. and Serwa, D. (2007), "Intra- and Inter-Regional Spillovers between Emerging Capital Markets around the World", Research in International Business and Finance, 21 (2), 203-221 
14. Golaka, C. Nath, (2002), "Integration of Global Equity Markets - A case for India", NSE News, November, pp.11-16.

15. Hahm, S (2003), "Transmission of Stock Returns and Volatility: The Case of Korea", The Journal of Korean Economy, 5 (1), 17-45.

16. Hamao, Y., Masulis R. W. and Ng V., (1990), "Correlations in Price Changes and Volatility across International Stock Markets", The Review of Financial Studies, Vol. 3 (2), 281-307.

17. Harris D. F. Richard and Anirut Pisedtasalasai, (2005), "Return and Volatility Spillovers Between Large and Small Stocks in the UK", Xfi Centre for Finance and Investment University of Exeter, UK Paper Number: 06/09.

18. Hashmi, A R and Xingyun, L, (2001), "Interlinkages among South East Asian Stock Markets (A Comparison Between Pre- and Post-1997-Crisis Periods)", Working Paper presented at the 10th International Tor Vergata Financial Conference, Rome, Italy Source: http://www.chass.utoronto.ca/ ahashmi/pdf_files/Hashmi_ECO2401.pdf

19. Hong Rim, and Robert Setaputra, (2008), "Studies On The Financial Integration And Market Efficiency: Empirical Evidence From Asia" IABR \& TLC Conference Proceedings San Juan, Puerto Rico, USA

20. Hsiao Frank, S.T., Hsiao M. W. and Yamashita A., (2003) "The Impact of The US Economy on The AsiaPacific Region: Does It Matter?”, Journal of Asian Economics, Vol. 14, 2003, 219-241. http://www.afaanz.org/web2005/papers/colthupg-FIN.pdf

21. Jang H. and Sul W., "The Asian Financial Crisis and the Co-Movement of Asian Stock Markets", Journal of Asian Economics, Vol. 13, 2002, 94-104.

22. Johnson, R., \& Soenen, L. (2002). Asian Economic Integration and Stock Market Comovement. Journal of Financial Research 25, 141-157.

23. Khan Masood Ahmad, Shahid Ashraf and Shahid Ahmed, (2005), "An Empirical Investigation of Causality and Dynamic Linkages: A Case of Indian and American Equity Markets", Prajnan, Vol.33, No. 3, pp.219-241.

24. Kim, S J (2005). "Information Leadership in the Advanced Asia-Pacific Stock Markets: Return, Volatility and Volume Information Spillovers from the U.S. and Japan," Journal of the Japanese \& International Economies, 19 (3), 338-365.

25. Kumar K., (2002), "Equity Market Interlinkages - A Case of US and India”, NSE News, November, pp.37.

26. Kuper.H and Lestano (2006) "Dynamic conditional correlation analysis of financial market interdependence: An application to Thailand and Indonesia" CCSO Working paper 2006/02, http://www.eco.rug.nl/ccso.

27. Laurence Fung and Ip-wing Yu, (2003), "Return and Volatility Spillovers in Hong Kong Financial Markets", http://ssrn.com/abstract=1331247.

28. Lucey, B. M., Voronkova, S. (2008), "Russian Equity Market Linkages Before and After the 1998 Crisis: Evidence from Stochastic and Regime-Switching Cointegration Tests", Journal of International Money and Finance (Forthcoming)

29. Manning, Neil, (2002), "Common Trends and Convergence? South East Asian Equity Markets, 19881999”, Journal of International Money and Finance 21, 183-202.

30. Morana, C. and Beltratti, A. (2008), "Comovements in international stock markets", Journal of International Financial Markets, Institutions and Money, 18 (1), 31-45.

31. Mukherjee, K.N. and Mishra, R. K. (2005), "Stock Market Interlinkages: A Study of Indian and World Equity Markets", Indian Journal of Commerce, 58 (1), 17 - 42.

32. Nalini Prava Tripathy,(2005), "Dynamic Relationship between Emerging Market and Developed Market: An Empirical Study in the Global Context", The ICFAI Journal of Applied Finance, pp.49-60.

33. Queensly Jeyanthi B.J., and Pandian (2008), "Am Empirical Study of Cointegration and Correlation among Indian, Emerging and Developed Markets", Vol. 14, No.11 pp.35 - 47

34. Ratanapakorna O. and Sharma S. C., (2002), "Interrelationships among Regional Stock Indices", Review of Financial Economics, Vol. 11, 91-108.

35. Sharma, Subhash C., and Praphan Wongbangpo, (2002), "Long-term Trends and Cycles in ASEAN Stock Markets", Review of Financial Economics 11, 299-315. 
36. Tan, K B and Tse, Y K (2001), "The Integration of the East and South-East Asian Equity Markets", Working Paper, National University of Singapore; Source:

https://mercury.smu.edu.sg/rsrchpubupload/1189/ICSEAD_paper.pdf.

37. Valadkhani, A., Chancharat†Dynamic, S. (2008), "Dynamic Linkages Between Thai and International Stock Markets", Journal of Economic Studies, 2008, http://ro.uow.edu.au/commpapers/354

38. Wang, Y., Gunasekarage, A. and Power D.M. (2005), "Return and Volatility Spillovers from Developed to Emerging Capital Markets: The Case of South Asia", Contemporary Studies in Economic and Financial Analysis, 86, 139-166.

39. Yang, J; Kolari, J W and Min, I (2002), "Stock Market Integration and Financial Crises: The Case of Asia," Applied Financial Economics, 13(7), 477-486.

\section{NOTES}

